\title{
Peran Mindfulness dalam Meningkatkan Behavioral Self Control Remaja
}

\author{
Lutfi Permana, Agus Abdul Rahman*, Ila Nurlaila Hidayat \\ Fakultas Psikologi UIN Sunan Gunung Djati Bandung \\ e-mail : agus.abdulrahman@uinsgd.ac.id
}

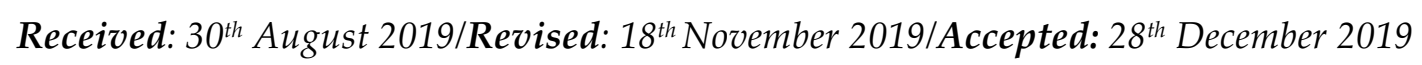

\begin{abstract}
One of the factors that encourage adolescents to engage in anti-social behavior is their low behavioral self control. It is important to identify factors that can improve adolescent behavioral self control. Many factors are thought to influence behavioral self control, including mindfulness. This study aimed to examine the extent of the contribution of mindfulness on behavioral self control. The number of respondents in this study were 243 students in one of the schools in the province of West Java. The data collected was analyzed using simple regression. The results showed that there was a positive influence of mindfulness on behavioral self control. The behavioral aspect of self control that is most affected by mindfulness is becoming aware.
\end{abstract}

Keywords: mindfulness, behavioral self control, becoming aware, adolescents

Abstrak. Salah satu faktor yang mendorong remaja terlibat dalam perilaku anti-sosial adalah kurangnya kemampuan mereka dalam mengontrol perilaku (low behavioral self control). Dalam rangka mengurangi keterlibatan remaja dalam perilaku anti-sosial tersebut, penting diidentifikasi faktor-faktor yang dapat meningkatkan behavioral self control remaja. Ada banyak faktor yang diduga berpengaruh terhadap behavioral self control, antara lain adalah mindfulness. Penelitian ini ditujukan untuk menguji sejauhmana kontribusi dari mindfulness terhadap behavioral self control. Jumlah subjek dalam penelitian ini sebanyak 243 orang siswa di salah satu sekolah yang ada di provinsi Jawa Barat. Data yang dikumpulkan dianalisis dengan menggunakan regresi sederhana. Hasil penelitian menunjukkan bahwa mindfulness berperan terhadap behavioral self control remaja. Aspek behavioral self control yang paling terpengaruh oleh mindfulness adalah aspek becoming aware.

Kata kunci: mindfulness, behavioral self control, becoming aware, remaja

Usia remaja merupakan usia peralihan dari masa anak menuju masa dewasa (Zimmerman, 2010). Di satu sisi, remaja belum sepenuhnya meninggalkan peran dan tugasnya sebagai anak, tapi di lain sisi, remaja pun belum sepenuhnya menghayati peran dan tugasnya sebagai orang dewasa. Tuntutan sosial pun kadang tidak konsisten. Remaja kadang diperlakukan sebagai seorang anak, padahal remaja merupakan usia yang ditandai dengan keinginan untuk bebas bertindak dan keinginan untuk terlibat dalam tindakantindakan yang beresiko (Arnett, 2000). Posisi inilah yang kemudian dapat menempatkan remaja pada kebingungan dan krisis, termasuk kebingungan terhadap dirinya sendiri. Tidak heran jika usia remaja disebut sebagai usia yang erat sekali dengan masa pencarian jati diri (Suryabrata, 2005), dan kurang mampu mengendalikan dirinya dengan baik 
(Santrock, 2002). Ketidakmampuan remaja dalam mengendalikan dirinya ini sebenarnya bisa dipahami. Namun, karena merupakan kompetensi yang sangat penting bagi remaja, maka kemampuan mengendalikan diri pada remaja ini harus mendapatkan perhatian serius. Beberapa penelitian menunjukkan pentingnya kemampuan mengendalikan diri ini, seperti penelitian yang menunjukkan bahwa kemampuan mengendalikan diri merupakan salah satu faktor yang berpengaruh besar terhadap munculnya perilaku antisosial (Wills, Walker, Mendoza, \& Ainette, 2006; Amenta, Borrani, Valdez, \& Tirado, 2012).

Self control merupakan kemampuan individu dalam menahan diri atau mengarahkan dirinya pada hal-hal yang lebih baik saat menghadapi godaan-godaan dari luar dirinya (Hoffman, Baumeister, Forster \& Vohs, 2012). Pengertian lain yang relatif sudah lama antara lain disampaikan oleh Averill (1973), yaitu bahwa self control sebagai kemampuan yang dimiliki individu dalam mengendalikan tindakan langsung terhadap rangsang dari lingkungan, pemahaman makna terhadap peristiwa yang terjadi, dan kendali terhadap alternatif suatu pilihan.

Self control bisa berfungsi untuk mencegah perilaku-perilaku yang tidak diharapkan dan mengurangi dampakdampak psikologis yang negatif akibat dari tekanan-tekanan lingkungan (Ghufron \& Risnawita, 2010). Averill (1973) menyebut self control ini dengan sebutan personal control yang meliputi yaitu behavioral control, cognitive control, dan decisional control. Behavioral control mengacu pada kemampuan mengendalikan perilaku yang dapat mengubah situasi yang tidak menyenangkan; cognitive control mengacu pada kemampuan mengendalikan upaya kognitif baik memilih atau memaknai situasi yang dianggap tidak menyenangkan; dan decisional control mengacu pada kemampuan mengendalikan alternatif perilaku yang mungkin dipilih dalam menghadapi situasi yang tidak menyenangkan (Cohen, Evans, Stokols, \& Krantz, 1986)

Pada penelitian ini, peneliti lebih tertarik dengan behavioral self control, yang merupakan bagian yang paling luar dari self control. Mahoney dan Thoresen (1974) menjelaskan bahwa behavioral self control merupakan kemampuan menyadari tindakannya sendiri untuk selanjutnya mengevaluasi, membimbing, mengarahkan dan mengkoordinasikan tindakannya sesuai dengan pertimbangan lingkungan tanpa paksaan eksternal. Behavioral self control merupakan bentuk perilaku individu yang dikendalikan dirinya agar perilaku tersebut sesuai dengan batasanbatasan yang ada pada lingkungan, dan memunculkan perilaku yang baik. Jadi, perilaku baik secara tidak langsung menunjukkan baiknya behavioral self control seseorang, dan perilaku buruk secara tidak langsung menunjukkan buruknya behavioral self control (Friese, Ostafin, \& Loschelder, 2016).

Behavioral self control merupakan kemampuan individu untuk mengubah atau mengenyampingkan respon dalam upaya mengalihkan gangguan-gangguan terhadap kecenderungan perilaku yang tidak diinginkan dan menahan diri dari 
perilaku-perilaku yang datang dari gangguan-gangguan tersebut (Tangney, Baumeister, \& Boone, 2004). Mahoney dan Thoresen (1974) menjelaskan bahwa seseorang akan mampu mengendalikan diri terutama dalam aspek perilaku dengan komponen-komponen yang yang terdiri dari: a) Becoming aware yaitu seseorang memiliki kesadaran untuk menerima diri, perilakunya, semua akibat dari perilakunya serta mampu untuk mengevaluasi perilakunya, b) Altering the environment yaitu seseorang memiliki kemampuan untuk menghindari situasi dan kondisi yang tidak boleh diikuti serta mampu mengubah dan merencanakan lingkungan seperti yang diharapkan, c) Altering the consequences behaviour yaitu seseorang memiliki kemampuan untuk memberikan hukuman atau hadiah (internal atau eksternal) dari perilaku yang dibuatnya.

Dari banyak faktor yang diduga berpengaruh terhadap behavioral self control adalah mindfullness yang merupakan salah satu faktor yang menarik untuk diuji pengaruhnya pada remaja. Penelitian sebelumnya menunjukkan bahwa mindfulness berpengaruh positif terhadap self control. Penelitian Friese, Ostafin, dan Loschelder (2016) menunjukkan bahwa mindfulness mampu meningkatkan kemampuan self control, disiplin diri, dan menurunkan reaksi emosional. Mindfulness juga berpengaruh terhadap perilaku baik ketika makan, konsumsi alkohol, dan perilaku agresi. Penelitian lain yang dilakukan oleh Panek, Bayer, Dal Cin dan Campbell (2015) menunjukkan bahwa mindfulness berpengaruh positif terhadap intensitas mengetik pesan singkat saat sedang mengendarai mobil dan berjalan. Mindfulness menjadi pengingat untuk tidak mengetik pesan singkat saat sedang mengendarai mobil dan berjalan yang merupakan perilaku membahayakan diri sendiri dan orang lain.

Mindfulness adalah aktivitas memfokuskan kesadaran pada suatu tujuan, dengan tidak menghakimi dan tidak menghindari kondisi yang tidak dapat dikuasai. Baer (2003) mendefinisikan mindfulness sebagai memusatkan kesadaran pada saat ini, menerima dan tidak menghakimi dengan penuh kesadaran terhadap pengalaman baik atau buruk yang terjadi di dalam maupun di luar dirinya. Mindfullness marupakan kondisi dimana seseorang benar-benar hadir dalam kondisi tertentu (Kabat-Zinn, 2003; Wood, 2013). Ia memiliki kesadaran penuh sehingga pikirannya tidak dibiarkan melayang pada hal-hal yang telah terjadi pada hari kemarin atau hal-hal yang akan direncanakan pada esok hari. Ia hanya memusatkan perhatiannya pada hal-hal yang sedang dikerjakan saat ini (Wood, 2013).

Baer, Smith dan Allen menjelaskan bahwa seseorang akan mampu mindfulness jika memiliki kesadaran diri dan penerimaan tanpa menilai. Berdasarkan beberapa penelitian sebelumnya, Keng, Smoski, dan Robins (2011) menyimpulkan bahwa elemen penting dari mindfulness itu adanya kesadaran terhadap apa yang dialami, dan mengalaminya dengan penerimaan tanpa penilaian. Lebih lanjut, Baer, Smith, dan Allen mengidentifikasi empat keterampilan mindfulness, yaitu mengamati (observe), menggambarkan (describe), bertindak dengan penuh 
kesadaran (act with awarness), dan menerima tanpa penilaian (accept without judgment).

Dalam konsep mindfulness, seseorang diharapkan memiliki kemampuan mengamati dan memperhatikan stimulus yang ada di sekitarnya (observe), dan juga menjelaskan stimulus tersebut (describe). Namun, penjelasan ini hanya sekedar untuk identifikasi fenomena saja, tanpa memberikan penjelasan yang luas dan tetap memusatkan perhatian pada saat ini. Dalam konsep mindfulness, seseorang diharapkan memiliki kemampuan untuk masuk ke dalam aktivitas dengan penuh perhatian tanpa perhatian yang terbagi-bagi, seakanakan seseorang menjadi satu bagian dengan aktivitas yang sedang dilakukannya tersebut. Hal tersebut akan membuatnya mampu untuk melakukan aktivitas dengan kesadaran penuh dan tidak terbawa begitu saja oleh kehidupannya (act with awarness). Terakhir, dalam mindfulness, seseorang diharapkan mampu menerima keadaan yang terjadi pada dirinya, tanpa ada respon spontan untuk mengubah, mengamati keterkaitannya dan anti terhadap pengalaman tersebut (accept without judgment).

\section{Metode}

\section{Partisipan Penelitian}

Partisipan penelitian ini terdiri dari siswa Madrasah Tsanawiyah di salah satu sekolah yang ada di suatu kota di Jawa Barat. Dengan menggunakan metode proportionate stratified random sampling, terdapat 243 siswa yang kemudian menjadi partisipan penelitian. Siswa dirandom berdasarkan level kelas, dengan tetap memperhatikan keseimbangan proporsi masing-masing kelas. Partisipan dari kelas VIII terdapat 116 siswa, dan partisipan dari kelas IX terdapat 127 siswa.

\section{Instrumen Penelitian}

Variabel Mindfulness diukur dengan menggunakan skala Assessment of Mindfulness by Self-Report dari The Kentucky Inventory of Mindfulness Skills (Baer, Smith \& Allen, 2004) yang terdiri dari 39 item, dan diadaptasi oleh peneliti sendiri. Butir-butir item dianalisis secara kualitatif, dan diujicobakan kembali. Variabel Behavioral self control diukur dengan menggunakan skala yang disusun oleh peneliti berdasarkan Behavioral Self Control dari Mahoney dan Thoresen (1974), yang terdiri dari 67 item. Uji validitas konstruk menunjukkan bahwa korelasi antara skor aspek dan skor totalnya termasuk sangat tinggi. Pada skala mindfulness, validitas konstruk aspek observe sebesar .945, aspek describe sebesar .766, aspek act with awareness sebesar .828, dan aspek act without judgment sebesar .663. Pada skala behavioral self control, validitas konstruk aspek becoming aware sebesar .906, aspek altering the environment sebesar .786, dan aspek altering the consequences behavior sebesar .812 .

$$
\text { Uji reliabilitas dengan }
$$
menggunakan Cronbach's Coefficient Alpha menunjukkan koefisien reliabilitas dari skala mindfulness adalah sebesar .87, sedangkan skala Behavioral Self Control adalah sebesar .84. Berdasarkan perhitungan tersebut, masing-masing skala 
dinyatakan reliabel untuk mengukur mindfulness dan behavioral self control.

\section{Analisis Data}

Data yang dikumpulkan dengan menggunakan skala mindfulness dan behavioral self control tersebut kemudian diolah dengan menggunakan analisis regresi sederhana. Sebelum analisis regresi sederhana dilakukan, terlebih dahulu dilakukan uji asumsi klasik, seperti uji normalitas, linieritas, dan homogenitas. Uji asumsi klasik menunjukkan data penelitian termasuk normal dan homogeny, serta hubungan antar variable termasuk linier.

\section{Hasil}

Hasil analisis deskriptif menunjukkan bahwa jumlah subjek yang kategori mindfulness-nya rendah $(49.38 \%)$ tidak terlalu jauh berbeda dengan subjek yang kategori mindfulness-nya tinggi (50.62). Demikian pula, jumlah subjek yang kategori behavioral self control-nya rendah (47.74\%) tidak terlalu jauh berbeda dengan subjek yang kategori behavioral self controlnya tinggi (52.26\%). Namun, secara umum bisa disimpulkan, subjek penelitian lebih cenderung mimiliki mindfulness dan behavioral self control di atas rata-rata.

Tabel 1.

Jumlah dan Persentase subjek penelitian berdasarkan variabel penelitian

\begin{tabular}{ccc}
\hline & Tinggi & Rendah \\
\hline Mindfulness & 123 orang & 120 orang \\
& $(50.62 \%)$ & $(49.38 \%)$ \\
Behavioral Self & 127 orang & 116 orang \\
Control & $(52.26 \%)$ & $(47.74 \%)$ \\
\hline
\end{tabular}

Uji hipotesis yang dilakukan dengan menggunakan regresi sederhana menunjukkan hasil bahwa model regresi yang diajukan dapat digunakan, yaitu bahwa mindfulness dapat memprediksi behavioral self control subjek penelitian, $\mathrm{F}(242)=32.113, p<.001, \mathrm{R}^{2}=.118$. Artinya, subjek yang memiliki mindfulness yang tinggi bisa diprediksikan memiliki behavioral self control yang tinggi. Namun, kemampuan mindfulness dalam memprediksi behavioral self control tersebut termasuk kategori rendah yaitu $11.8 \%$. Artinya, ada faktor-faktor lain yang berpengaruh terhadap behavioral self control seseorang. Prediksi mindfulness terhadap behavioral self control bisa dilakukan dengan menggunakan persamaan regresi berikut: $Y$ $=56.602+.343 X$. Artinya, setiap kenaikan satu poin skor mindfulness, akan meningkatkan 56.945 poin behavioral self control.

Analisis lebih lanjut dengan menggunakan analisis korelasi menunjukkan bahwa mindfulness berhubungan positif dengan semua aspek dari behavioral self control. Data menunjukkan bahwa mindfulness memiliki hubungan yang lebih tinggi dengan aspek becoming awareness $(\mathrm{r}=.332, \quad p<.001)$ dibanding dengan kedua variabel behavioral self control lainnya, altering the environment $(\mathrm{r}=.197, \quad p<.002)$ dan altering the consequences behavior $(\mathrm{r}=.255, \quad p<.001)$. Analisis berikutnya menunjukkan bahwa korelasi aspek-aspek mindfulness dengan behavioral self control tidak semuanya positif. Data menunjukkan bahwa kecuali aspek accept without judgment, semua aspek 
mindfulness berhubungan positif dengan behavioral self control.

Tabel 2.

Hubungan antar aspek behavioral self-control dan Mindfulness

\begin{tabular}{lcc}
\hline $\begin{array}{c}\text { Aspek Behavioral } \\
\text { Self-control }\end{array}$ & $\begin{array}{c}\text { Mindfulness } \\
\text { (nilair) }\end{array}$ & $\begin{array}{c}\text { Sig. } \\
\text { (nilaip) }\end{array}$ \\
\hline $\begin{array}{l}\text { Becoming aware } \\
\text { Altering the } \\
\text { environment }\end{array}$ & .332 & .001 \\
Altering the & .255 & .001 \\
$\begin{array}{l}\text { consequences } \\
\text { behavior }\end{array}$ & .197 & .002 \\
\hline
\end{tabular}

\section{Diskusi}

Hasil analisis deskriptif menunjukkan bahwa jumlah subjek yang memiliki mindfulness dan behavioral self control yang tinggi dan rendah ternyata cukup seimbang, atau tidak terlalu beda secara kuantitatif. Hal ini menarik, karena subjek penelitian masih termasuk remaja awal yang karakteristik psikologisnya masih dalam proses pembentukan, tapi sudah memiliki mindfulness dan behavioral self control dalam kategori rata-rata. Usia remaja memang merupakan usia yang perkembangan aspek-aspek psikologisnya belum mencapai kematangan, baik pada aspek kognitif, emosi, sosial, moral, ataupun aspek biologis. Oleh karena itu, menurut Hurlock (2003), usia remaja memang memerlukan pendampingan, khususnya dari orang-orang dewasa.

Subjek penelitian memiliki mindfulness dan behavioral self control dalam kategori rata-rata dimungkinkan karena mereka mendapatkan pembelajaran keagamaan yang cukup kental, baik secara kognitif, emosi, ataupun perilaku. Menurut Kay, Gaucher, McGregor, dan Nash (2010), agama dengan keyakinannya kepada sang pencipta yang maha kuasa bisa berperan sebagai kontrol eksternal yang mengendalikan perilaku penganutnya. McCullough dan Carter (2013) pun menulis bahwa agama berhubungan dengan self control dan self regulation. Menurut McCullough dan Carter (2013) keyakinan agama memungkinkan seseorang mempunyai tujuan yang jelas, membuatnya memiliki self monitoring dan implicit self regulation yang tinggi, dan lain-lain.

Penelitian ini menunjukkan bahwa mindfulness berperan terhadap behavioral self control dan behavioral self control ini bisa diprediksikan berdasarkan mindfulness. Seperti penelitian sebelumnya yang dilakukan oleh Friese, Ostafin dan Loschelder (2016) yang menunjukkan bahwa mindfulness berpengaruh terhadap good behavioral (perilaku baik) yang mana good behavioral ini menunjukkan behavioral self control yang baik juga. Begitu juga dengan Mahoney dan Thoresen (1974) yang menyatakan salah satu yang mempengaruhi behavioral self control adalah becoming aware. Artinya apabila orang yang memiliki mindfulness yang tinggi bisa diprediksi juga memiliki behavioral self control yang tinggi pula, begitu sebaliknya orang yang memiliki mindfulness yang rendah juga bisa diprediksi memiliki behavioral self control yang rendah.

\section{Kesimpulan}

Berdasarkan penelitian yang sudah dilakukan, dapat disimpulkan bahwa 
mindfulness berperan dan dapat memprediksi behavioral self control. Peran mindfulness terhadap behavioral self control tersebut termasuk rendah. Mindfulness berhubungan positif dengan semua aspek behavioral self control, tapi hubungannya dengan aspek becoming aware termasuk paling tinggi.

\section{Saran}

Penelitian berikutnya sebaiknya menguji variabel-variabel lain yang dapat memprediksi behavioral self control, selain variable mindfulness. Menggunakan beberapa variable sebagai prediktor juga sebaiknya dilakukan agar teridentifikasi arah dan kekuatan pengaruh masingmasing variabel.

\section{Daftar Pustaka}

Armenta, M.F., Borrani, J., Valdez, P., \& Tirado, H. (2012). Self Control, selfregulation, and juvenile delinquency, in Vassilis Barkoukis (Eds). Psychology of Self-regulation. Nova Science Publisher, 147-168.

Arnett, JJ. (2000). Emerging adulthood: A theory of Development from the late teens through the twenties. American psychologist, 55, 469-480.

Averill, J.F.(1973). Personal Control Over Averssive Stimuli and It's Relationship to Stress. Psychological Bulletin. No. 80, 286-303.

Baer, R. A (2003) Mindfulness Training as a Clinical Intervention: A Conceptual and Empirical Review. Clinical Psychology in Science \& Practice. 10, 125143.
Baer, R. A., Smith, G. T., \& Allen, K. B. (2004). Assessment of Mindfulness by Self-Report The Kentucky Inventory of Mindfulness Skills. Assessment. Vol. 11, No. 3, 191-206.

Brown, K. W., \& Ryan, R. M. (2003). The Benefits of Being Present: Mindfulness and It's Role in Psychological Wellbeing. Journal of Personality and Social Psychology. 84, 822-848.

Cohen, S., Evans, G.W., Stokols, D., \& Krantz, D.S. (1986). Behavior, Health, and Environmental Stress. New York: Springer Science Business Media.

Friese, M. Ostafin, B., \& Loschelder, D.D.(2016). Mindfulness as an Intervention to Improve Self Control. Germany: Department of Psychology, Division of Social Psychology, Saarland University.

Ghufron, M.N \& Risnawita, R.S. (2010). Teori-Teori Psikologi. Yogyakarta: ArRuzz.

Hofmann, W., Baumeister, R.F., Forster, G., \& Vohs, K.D. (2012). Everyday temptations: An experience-sampling study of desire, conflict, and selfcontrol. Journal of Personality and Social Psychology, 201, 1318-1335.

Hurlock, E.B. (2003). Psikologi Perkembangan Suatu Pendekatan Sepanjang Rentang Kehidupan. Jakarta : Erlangga.

Kabat-Zinn, J. (2003). Mindfulness-Based Interventions in Context: Past, Present, and Future. Clinical Psychology: Science and Practise. 10, 144-156.

Kay, A.C., Gaucher, D., McGregor, I., \& Nash, Kyle (2010). Religious Belief as Compensatory Control. Personality and social psychology review, 14(1), 37-48. 
Keng, Shian-Ling, Smoski, M.J., \& Robins, C.J. (2011). Effects of Mindfulness on Psychological Health: A Review of Empirical Studies, 31(6), 1041-1056, do:10.1061/j.cpr.2011.04.006.

Mahoney, M. J., \& Thoresen, M.J. (1974). Behavioral Self Control. New York: Holt, Rinehart and Winston.

McCullough, M.E., \& Carter, E.C. (2013). Religion, self control, self regulation: How and why are they related? In K.I. Pargament, J.J. Exline, \& J.W. Jones (Eds), APA Handbook of Psychology, religion, and spirituality: Context, theory, and research. Washington, DC: APA.

Panek, E. L., Bayer, J. B., Dal Cin, S., \& Campbell, S. W. (2015). Automaticity, Mindfulness, and Self-Control as Predictors of Dangerous Texting Behavior. Journal of Mobile Media $\mathcal{E}$ Communication. No.3, 383-400.

Rahman, A.A. (2016). Metode Penelitian Psikologi: Langkah Cerdas Menyelesaikan Skripsi.Bandung: Rosda.
Santrock, J.W. (2002). Life-Span Development: Perkembangan Masa Hidup. Jakarta: Erlangga Press.

Suryabrata, S (2005). Psikologi Pendidikan. Jakarta: PT Grafindo Perkasa.

Tangney, J.P., Baumeister, R.F., \& Boone, A.L. (2004). High Self Control Predict Good Adjusment, Less Pathology, Better Grades and Interpersonal Succes. Journal of Personality. 72 (2), 271-282.

Wills, T. A., Walker, C., Mendoza, D., \& Ainette, M. G. (2006). Behavioral and emotional self-control: Relations to substance use in samples of middle and high school students. Psychology of Addictive Behaviors, 20(3), 265-278.

Wood, J.T.(2013). Komunikasi Interpersonal Dalam Interaksi Keseharian. Jakarta: Salemba Humanika.

Zimmerman, M.A. (2010). Natural Metntors, Mental Health, and Risk Behaviors: A Longitudinal Analysis of African American Adolescents Transitioning into Adulthood, 46(1-2), 36-48, doi: 10.1007/s10464-010-9325-x. 